\title{
ICE CALVING AND DEFORMATION FROM ANTARCTIC ICE MARGINS USING RISAT-1 CIRCULAR POLARIZATION SAR DATA
}

\author{
P. Jayaprasad*, D. Ram Rajak, Rajkumar Kamaljit Singh, Sandip R. Oza, Rashmi Sharma and Raj Kumar \\ Atmospheric and Oceanic Sciences Group, EPSA. \\ Space Applications Centre (ISRO), Ahmedabad - 380015, India - \\ (jayaprasadp, rajakdr, rksingh, sandipoza, rashmi, rksharma)@sac.isro.gov.in
}

\section{Commission VIII, WG VIII/6}

KEY WORDS: SAR, Ice Calving, change detection, RISAT-1, ISEA

\begin{abstract}
:
In the present study, quantification of spatial and temporal changes has been carried out between Indian Antarctic Research station Bharati and Amery ice shelf by monitoring the ice margins using RISAT-1 Synthetic Aperture Radar (SAR) data. Spatio-temporal change detection was carried out by comparing the feature's geographic locations from geometrically rectified SAR data from RISAT-1 (Dec. 2013), Radarsat-2 (Feb. 2013), and Antarctic Mapping Mission products of Radarsat-1 (1997 \& 2000). We report large scale disintegrations at two prominent glacier tongues namely Polar Record Glacier (PRG) and Polar Times Glacier(PTG). The results are verified against in-situ ground observations made during Summer period of 33rd ISEA (Dec. 2013 - Feb. 2014 ) and MODIS images from NSIDC archive. Polar Record Glacier Tongue (PRGT) was drastically deformed by $135.8 \mathrm{~km}^{2}$ and Polar Times Glacier Tongue (PTGT) was partly calved by $195.6 \mathrm{~km}^{2}$ and moved away by $\sim 23 \mathrm{~km}$ especially between February and December 2013.
\end{abstract}

\section{INTRODUCTION}

Antarctica is a unique continent surrounded by ocean, where the large scale changes have an indirect indication on the global climate variation. Unusual sea ice freeze/thaw cycle, ice sheet/shelves melting, ice margin disintegration etc. are some major indicators of changing climate. Ice sheet, glaciers, ice shelf terminating at oceans may result in formation of icebergs through the process of calving. These icebergs create hindrance to safer ship navigation and represent a significant hazard to polar shipping and operations. India presently has two research stations Maitri and Bharati at Schirmarcher Oasis and Larsemann Hills respectively. Indian Scientific Expedition to Antarctica (ISEA) has evolved as a regular programme undertaken by Ministry of Earth Sciences and coordinated by National Centre for Antarctic and Oceanic Research (NCAOR) during the last 33 years. Space Applications Centre (SAC) / Indian Space Research Organisation (ISRO) is providing Advisory to the ship voyage for the safe passage of our scientific and logistic team. Hence it is very important to monitor the coastal region near Bharati and Maitri as far as the safer ship navigation is concerned. Calving of icebergs is an important component of mass loss from the polar ice sheets and glaciers in many parts of the world especially in Antarctic ice margins. Calving rates can increase dramatically in response to increases in velocity and / or retreat of the glacier margin, with important implications for sea level change. Figure 1 shows the locations and photographs of Indian Antarctic research stations along with 33rd ISEA team in front of Bharati.

Ice calving is the sudden disintegration of large chunk of iceberg from ice sheet, glacier, ice shelf, ice berg or crevasses. Mass is lost from ice shelves / glacier tongue primarily through two processes: basal melting and iceberg calving (Rignot et al., 2013). Mass is also added to some ice shelves through refreezing of marine ice on their base. Rifts form large-scale detachment boundaries (Joughin and MacAyeal, 2005), and their formation and propagation is a precursor to iceberg calving (Fricker et al., 2005). The calving of icebergs is also a key factor, both in terms of ice-sheet mass balance and its impact on ocean properties and circulation. It also plays a key role in determining the distribution of both pack ice and fast ice (Massom, 2010) and are sites of polynya formation. Icebergs are formed either by the calving of the seaward margins of floating glacier tongues or ice shelves or by the fragmentation of existing icebergs. Iceberg production rates vary considerably in both time and space, depending on complex interactions involving outlet glacier velocity, degree of crevassing, temperature, sea ice conditions and extent, tidal forcing, and ocean waves and swell and their variability.

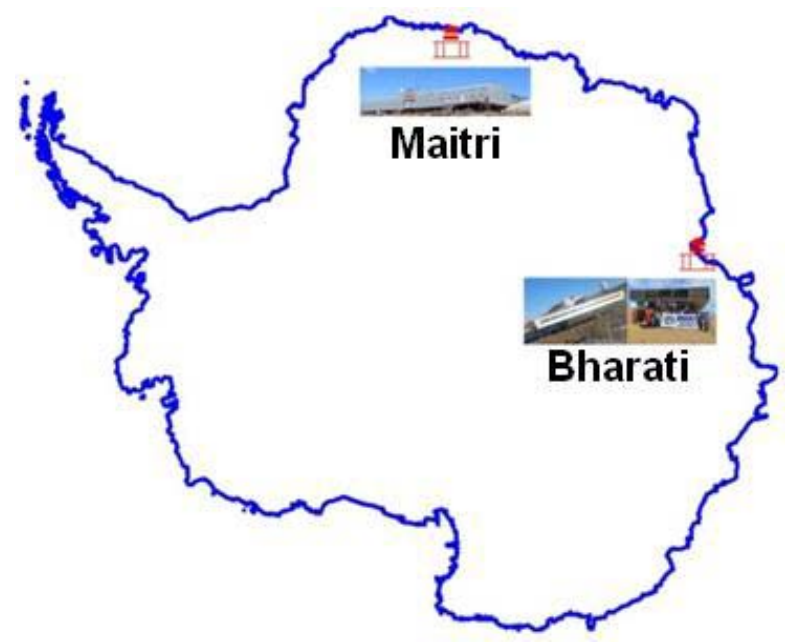

Figure 1. Indian Antarctic Research Stations Bharati and Maitri.

\footnotetext{
* Corresponding Author
} 
Benn et. al. (2007) carried out a review of different aspects of the calving problem and outlined a new framework for representing calving processes in ice sheet models. The past and present extent of calving glaciers is of particular importance because their dynamic behaviour is at least partially de-coupled from climate, with factors other than variations in the equilibrium line altitude being major controls on the position, and rate of advance or retreat, of calving termini (Warren, 1991, Fischer and Powell, 1998; Nick and Oerlemans, 2006).

Space borne SARs are well-suited for the detection and size determination of small to medium icebergs by spatial and texture analysis, as these generally form bright radar targets that can generally be distinguished from the background sea ice or ocean signal (Willis et al., 1996). In their analysis of ice-shelf front behaviour using radar altimeter data, Zwally et al. (2002c) further suggested that large-embayment Antarctic ice shelves tend to break up in response to the cumulative effects of tideinduced fixing, while the calving of thinner, marginal ice shelves occurs in response to the cumulative effects of swellinduced fixing. Another study, by Massom (2003), used ERS and JERS-1 SAR and Radarsat-1 ScanSAR data to monitor the calving of the Ninnis Glacier in 2000, and found that this event was far from instantaneous. Rather, it took 10 years to complete, due in part to complex bathymetric and pack/fast ice conditions around the glacier tongue (with fast ice). Zhou et. al. (2012) used a combination of SAR interferometry, offset tracking and feature tracking to measure the ice flow velocity of the Polar Record Glacier and the calved iceberg. In their paper they have shown an image of Polar Record Glacier in 1973 with the portion of PRGT discussed in this paper completely missing. Brunt et. al. (2011) in their paper presented the first observational evidence that a Northern Hemisphere tsunami triggered Antarctic ice-shelf calving more than 13, $000 \mathrm{~km}$ away. Stevens et. al (2013) attributed the Erebus Glacier Tongue calving event to ocean currents. Christine et al. (2013) mapped surface structures of all ice shelves and glacier tongues around Antarctica and classified the surface structures relative to the calving front ice fronts.

India's Radar Imaging Satellite-1 (RISAT-1) was successfully launched from Sriharikota, India on 26 April 2012. It is orbiting at $536 \mathrm{~km}$ sun-synchronous dawn-dusk circular orbit. It is a C band SAR (5.35 GHz) with a capability of obtaining single (HH/HV/VV/VH), dual $(\mathrm{HH}+\mathrm{HV} / \mathrm{VV}+\mathrm{VH})$ and quad polarization data $(\mathrm{HH}+\mathrm{HV}+\mathrm{VV}+\mathrm{VH})$ RISAT SAR has unique Hybrid polarimetry modes, where signal is transmitted in circular polarization and signal is simultaneously received in $\mathrm{H}$ and $\mathrm{V}$ polarization. It has five acquisition modes. They are High Resolution Spotlight Mode (HRS), Fine Resolution Stripmap Mode -1 (FRS-1), Fine Resolution Stripmap Mode-2 (FRS-2), Medium Resolution ScanSAR Mode (MRS) and Coarse Resolution ScanSAR Mode (CRS). Standard acquisition is in MRS mode with $25 \mathrm{~m}$ resolution and $115 \mathrm{~km}$ swath with a repetivity of 25 days. CRS Mode provides data at $50 \mathrm{~m}$ resolution for coverage of $240 \mathrm{~km}$ with a repetivity of 13 days.

The present study is an attempt to monitor and quantify the large scale disintegration/calving from Antarctic ice margins especially between Larsmann Hills and Amery Ice Shelf. Two major glacier tongues in the Ingrid Christensen Coast, namely Polar Record Glacier Tongue (PRGT) and Polar Times Glacier Tongue (PTGT) were calved / deformed severely as observed during an aerial survey conducted during $33^{\text {rd }}$ ISEA. The spatio temporal change analysis was carried out using RISAT- 1 data Radarsat-2 data, Radarsat-1 data of Radar Antarctic Mapping
Project (RAMP): Antartic Mapping Mission-1 (AMM-1) and Modified Antarctic Mapping Mission (MAMM)) (Jezek, 1998) along with the ancillary data. The approximate period of calving event was verified with Moderate Resolution Imaging Spectroradiometer (MODIS) data onboard Terra/Acqua Satellites achieved at National Snow and Ice Data Center (NSIDC).

\section{OBJECTIVE}

The Antarctic Ice margins between Larsemann Hills and Amery Ice shelf is a potential region for ice loss as there are a number of glaciers in this area. During 33rd ISEA, an aerial survey conducted from Indian research station Bharati on Larsmann Hills to Amery has shown that lot of disintegration is taking place especially on Glacier fronts and a remarkable change was observed on PRGT and PTGT. The objective of the study is to monitor the calving and disintegration of large ice bergs on the glacier tongues of PRG and PTG and quantify the large scale changes happening there.

\section{STUDY AREA}

Part of Antarctic Ice Margin between Indian Research station Bharati and Amery Ice Shelf was monitored and change analysis was carried out for the present study. The ice margin between these areas contains a large number of glaciers. A drastic change had happened during the last 15 years on the glacier tongues of both Polar Record Glacier (69 $\left.45^{\circ} \mathrm{S} 75^{\circ} 30^{\prime} \mathrm{E}\right)$ and Polar Times Glacier $\left(69^{\circ} 46^{\prime} \mathrm{S} 74^{\circ} 35^{\prime} \mathrm{E}\right)$ and was observed by us during Antarctic expedition. Polar Record Glacier is a large glacier flowing between Meknattane Nunataks and Dodd Island to the central part of Publications Ice Shelf. Polar Times Glacier is flowing between Svarthausen Nunatak and Boyd Nunatak into the western part of Publications Ice Shelf. Both are originating from Ingrid Christensen Coast to Prydz Bay.

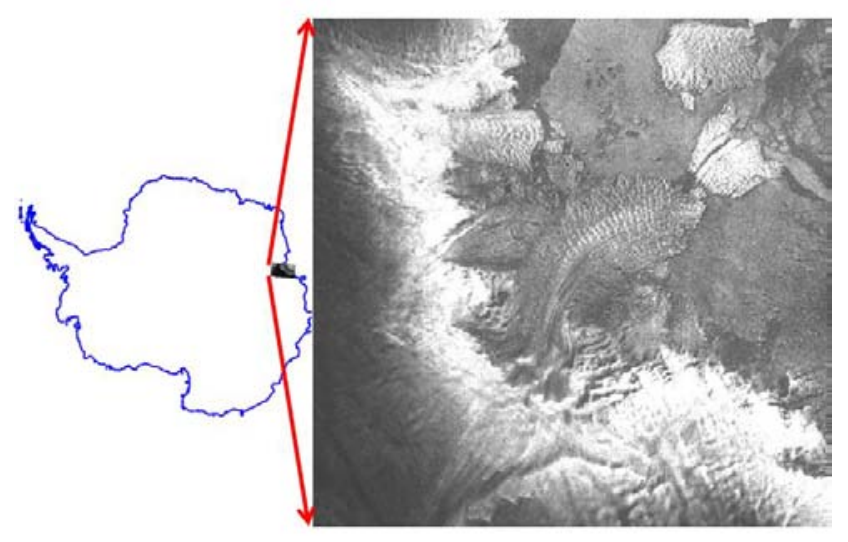

Figure 2. RISAT-1 CRS image of the study area

\section{DATA}

The data include RISAT -1 (MRS and CRS data: Dec 2013), Radarsat-2 (ScanSAR Wide: Feb. 2013), Radarsat Antarctic Mapping Project (RAMP)- Antarctic Mapping Mission-1, AMM1(1997) and Modified Antarctic Mapping Mission, MAMM (2000) products, Ancillary information collected during the 33rd ISEA and Geotagged photographs. MODIS data was also used to confirm the exact period in which the actual calving has taken place. 


\section{METHODOLOGY:}

The methodology broadly consists of spatio temporal change detection of Antarctic margins between Bharati peninsula and Amery Ice Shelf with specific emphasis given to the drastic change that happened to the two glacier tongues PRGT and PTGT. The major component of the work involve mosaic generation of the Radarsat-1 individual tiles from AMM-1 and MAMM products (Byrd Polar Research Center), co-registration of the RADARSAT-1(AMM-1, MAMM) RADARSAT-2 and RISAT-1, change detection analysis, confirming the time of calving using MODIS from the archived data. The methodology and is depicted in Figure 3. AMM-1 and MAMM image tiles were mosaicked separately. The georeferenced tiles SR (41-42; 43-44) and SQ (41-42; 43-44) are exported to geotiff format from the native format. Mosaicking of the images were carried out by taking maximum pixel value in the overlap area using Commercially Off The Shell (COTS) package (ERDAS). RISAT-1 CRS AND MRS Level - 2 Georeferenced products were procured (National Remote Sensing Centre) during the $33^{\text {rd }}$ ISEA for sea ice analysis for the safe navigation. These products are ortho-rectified products. The mosaic of the CRS image was carried out and a subset of the product of the study area was made. Radarsat-2 image was georeferenced with respect to AMM-1 and MAMM products. A multi temporal layer stack was generated. On screen digitization of the iceberg calving was carried out to quantify the area and drift length. Multi-temporal MODIS data taken from National Snow and Ice Data Centre (NSIDC) was used to verify the time of calving. Change detection analysis will take two images before and after the change had occurred and generate a difference image and an image highlighting the various classes of changes. Quantification of the area and drift was carried out by onscreen digitisation of the co registered images of respective year.

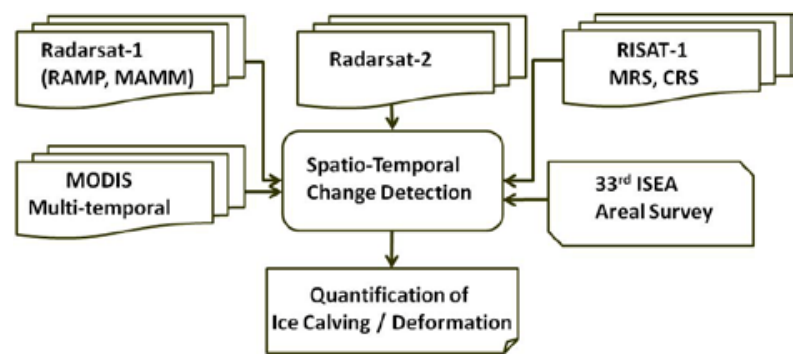

Figure 3. Flowchart of the quantification of ice calving

\section{RESULTS AND DISCUSSION}

Figure 4 shows a colour composite prepared from Circular Polarisation RISAT-1 MRS data (RH/RV/RH-RV). Various ice features e.g. ice sheet, glacier tongue, fast ice iceberg etc around the Larsemann Hills are marked on the image. Photographs of corresponding features are shown in Figure 5 collected during the $33^{\text {rd }}$ ISEA using Digital Single Lens Reflex (DSLR) geotagged camera. While carrying out an aerial survey, during 33rd ISEA, it was observed that a drastic change had happened in the glacier tongues of PRG and PTG in comparison with those observed in February 2013 (RADARSAT-2). The RISAT-1 data acquired on 19 Dec. 2013 shows the large scale ice calving and disintegration in these margins. This prompted us to analyse the available past data to quantify the changes.

Figure 6 shows the co-registered images from RISAT-1, Radarsat-2, Radarsat-1 (AMM-1 and MAMM). Regions around PRGT and PTGT are shown in circles. One can clearly notice the large changes between Feb. and Dec. 2013. In order to assess the exact month of the glacier tongue calving, image interpretation of MODIS data from NSIDC for the period 2002 to 2014 was carried out from the archived Amery Ice Shelf data. Some of the cloud free images from 2009 to 2013 are shown in Figure 7. These images helped us to confirm the calving had taken place between second half of March and August 2013 as the displaced icebergs are evident on 1 Sept. 2013 image. Cloud free images from April to August 2013 period are not available in the archive.

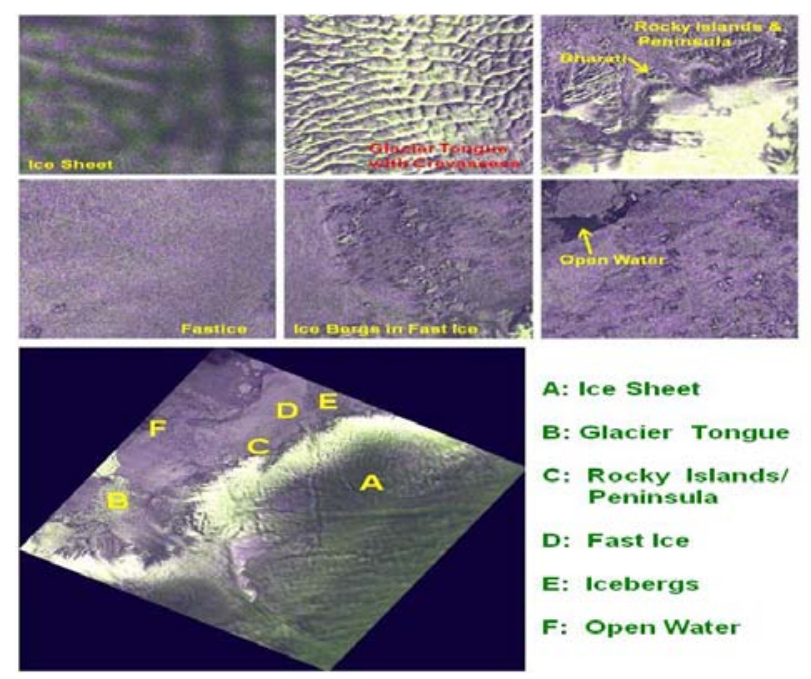

Figure 4. Antarctic Ice Features on RISAT-1 Circular Poalrisation data (FCC: RH/RV/RH-RV)

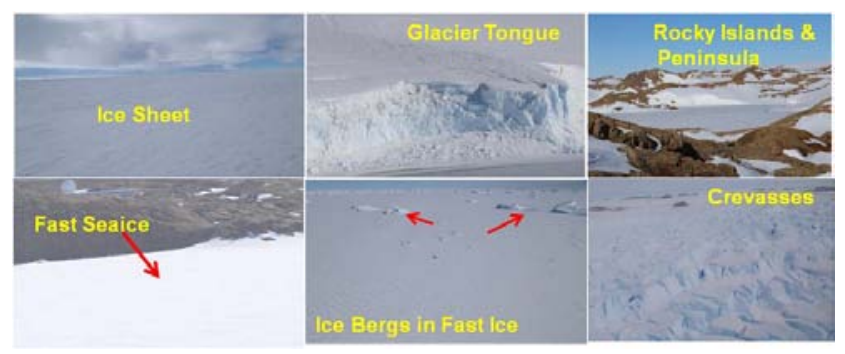

Figure 5. Digital photographs of the Antarctic ice features

The presence of sea water intruding more into the coast of the Publication Ice Shelf causing large chunk of ice shelf / fast ice that melted away during the summer of 2013 from Publication Ice Shelf (Figure 7 MODIS image of 15 March 2013) may be considered as a triggering factor for the calving. The MODIS image of 01 Sept. 2013 shows the ice calving/ deformation of the two glaciers as represented by the arrows.

Figure 8 shows the vectors in blue (2000), pink (Feb. 2013) and red (Dec. 2013) colours extracted from the respective temporal SAR images. The line vector represent the drift of icebergs from PTGT and polygon vector represent area of the respective icebergs that was intact / calved away from the two glacier tongues. In 1997, currently calved out icebergs were joined to glacier tongue and the crevasses were thin and shallow. In 2000, cracks appeared on glacier tongue and widening of the crevasses initiated. A portion of PTGT with an area of 203.3 $\mathrm{km}^{2}$ was detached and moved away $0.6 \mathrm{~km}$ between 1997 and 2000. Radarsat-2 data shows the same portion of PTGT with area $191.7 \mathrm{~km}^{2}$ was detached and moved away $8.3 \mathrm{~km}$ in the 
fast ice between 2000 and 2013 Feb. Between 2013 Feb. to 2013 Dec. the portion of PTGT has moved $23 \mathrm{~km}$ towards Amery ice shelf with an area of $195.6 \mathrm{~km}^{2}$.
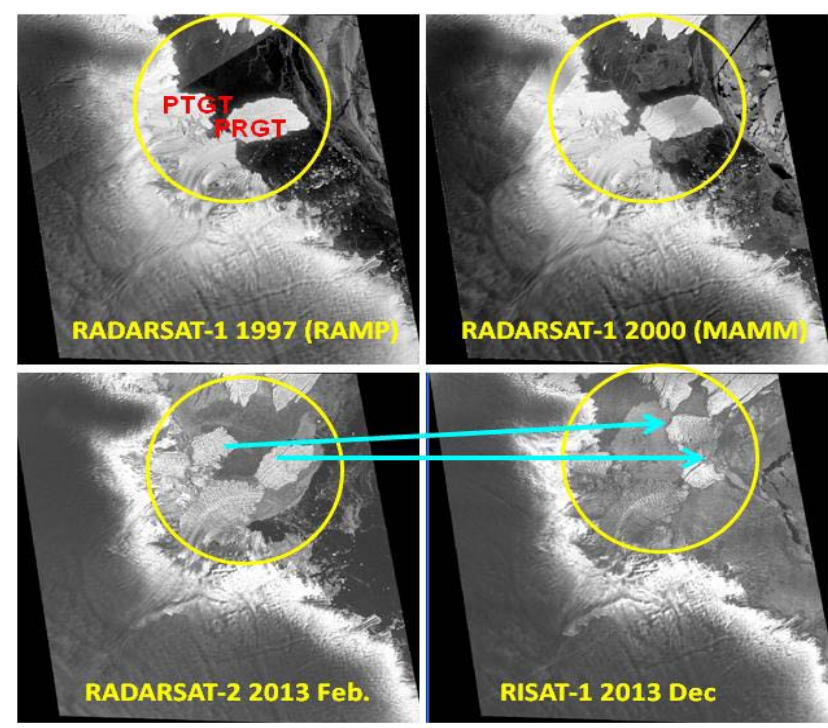

Figure 6.Temporal changes on Glacier Tongues

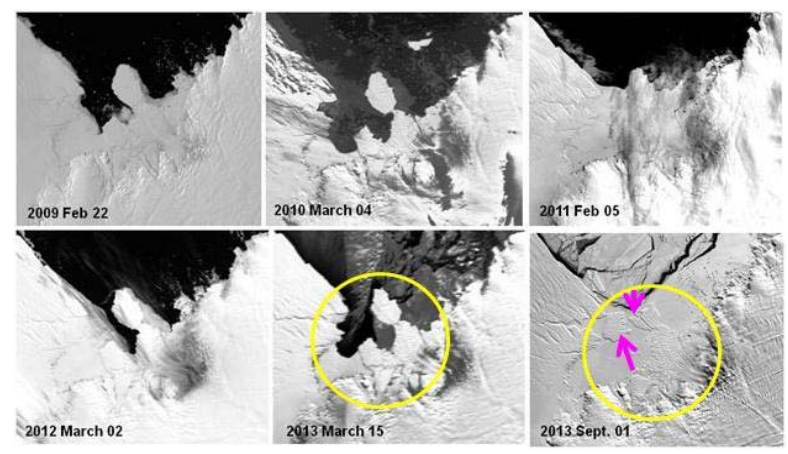

Figure 7. MODIS image for qualitative analysis of ice calving

A portion of PRGT with $404.6 \mathrm{~km}^{2}$ was intact in 2000 with the rest of the tongue. 2013 Feb. The same portion of the PRGT was reduced to an area of $292.2 \mathrm{~km}^{2}$ during Feb. 2013. The portion of PRGT was reduced further to $156.4 \mathrm{~km}^{2}$ in Dec. 2013.

Cloud free MODIS imagery of Sept. 01, 2013 confirms that the event had happened between second half of March and August 2013. As evident from AMM-1, MAMM and Radarsat-2, the iceberg calved from the Glacier tongues with wider crevasses was intact over a long period of time. An earthquake of 7.3 magnitude struck in 15 July, 2013 south of Bristol Island in the South Sandwich Islands (http://earthquake.usgs.gov/). It is possible that this part of east Antarctica got impacted and calving of these ice frontal margin initiated. Impact of a far away earthquake on Antarctic ice calving was reported by Brunt et. al. (2010).

Figure 9 shows the change detection analysis carried out during Feb. and Dec. 2013. The dark shades are the region of decrease in grey values less than $80 \%$ and Bright regions represents the regions of increase of pixel values more than $80 \%$. Here also one can extract automatically the areas of drastic changes.

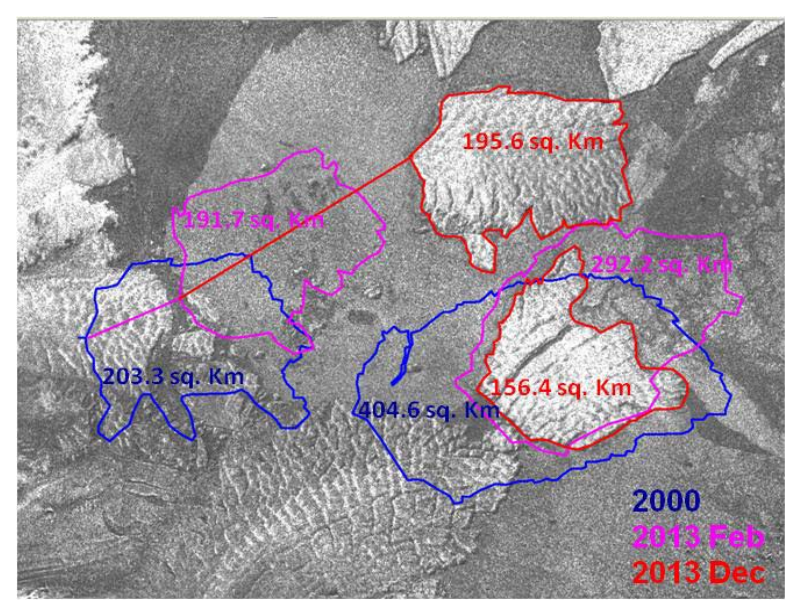

Figure 8. Quantification of Calving

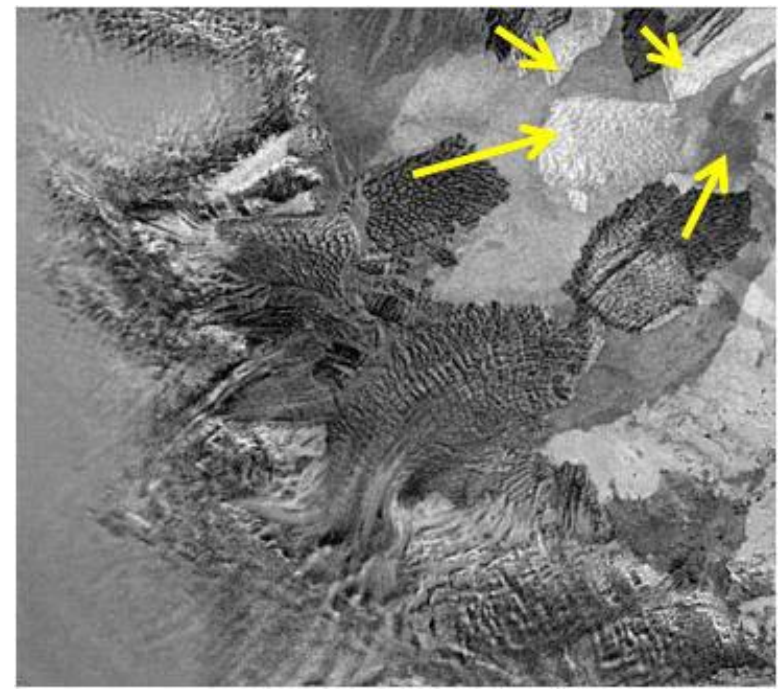

Figure 9. Change Detection Analysis: Feb. (Radarsat-2)and Dec. (RISAT-1) 2013

\section{CONCLUSION}

Large scale calving of icebergs from glacier tongue and deformation was observed in the analysis of SAR data of 1997, 2000 and 2013. The rift propagation, basal melting, crevasses widening, sea water penetration into the crevasses till the base of the floating glacier tongues are the processes before ice calving. Large chunk of iceberg was calved from Polar Times Glacier Tongue (PTGT) and deformed / calved from Polar Record Glacier Tongue (PRGT) between second half of March and August 2013. This may be attributed to the large scale disintegration of ice shelf / fast ice during the summer of 2013 near Prydz bay and may be attributed to the 7.3 magnitude earth quake that struck on July 15, 2013 south of Bristol Island in the South Sandwich Islands of Antarctica. Sea water intrusion in to the Publication ice shelf during March 2013 may accelerated calving processes. PRGT was Calved /deformed by $135.8 \mathrm{~km}^{2}$ and PTGT was calved by $\sim 195.6 \mathrm{~km}^{2}$ and moved away by $\sim 23$ $\mathrm{km}$ especially between February and December 2013. Analysis of temporal MODIS data and the observations made during 33rd ISEA support these SAR data based inferences.

Identification of Hot Spots regions in Antarctica, regular monitoring of these hot spots, quantification of these changes 
and impact of these changes locally as well as globally using SAR, Altimeter and Scatterometer data are the main targets for future course of action.

\section{ACKNOWLEDGEMENTS}

We would like to acknowledge our sincere thanks to Director SAC for his constant inspiration for carrying out Polar science studies at the centre and allowing two of us to participate in the 33rd ISEA. We also thank Deputy Director EPSA, for his support and guidance to this programme. Our thanks are also to Director NCAOR and his team for making a stage for 33rd ISEA participation and formulating the requirements. Special thanks are due to the team at NRSC for their help in data acquisition.

\section{REFERENCES}

Benn, D. I., Warren C. R., Mottram , R. H., 2007. Calving processes and the dynamics of calving glaciers, Earth-Science Reviews, 82 (2007) 143-179.

Brunt, K.M., E. A. OKAL,2 D. R. MacAyeal. 2011. Antarctic ice-shelf calving triggered by the Honshu (Japan) earthquake and tsunami, March 2011. Journal of Glaciology, 57( 205), 785-788.

Byrd Polar Research Center, The Ohio State University: Amm1and Mamm Products Bprc.Osu.Edu/Rsl/Radarsat/Data.

Christine W, Daniela J., Wolfgang D., 2013. Calving Fronts of Antarctica: Mapping and Classification. Remote Sens. 5, 63056322; doi:10.3390/rs5126305.

http://earthquake.usgs.gov/.

Fischer, M.P., Powell, R.D., 1998. A simple model for the influence of push-morainal banks on the calving and stability of glacial tidewater termini. Journal of Glaciology 44, 31- 41.

Fricker, H.A., N.W. Young, I. Allison and R. Coleman. 2002. Iceberg calving from the Amery Ice Shelf, East Antarctica. Ann. Glaciol., 34, 241-246.

Jezek, K. Sohn, H. Noltimier, K., 1998. The Radarsat Antarctic Mapping Project. In "Proceedings of IEEE International Geoscience and Remote Sensing Symposium Proceedings, IGARSS '98", Seattle, WA, USA, 6-10 July 1998; Volume 5, pp. 2462-2464.

Joughin, I., MacAyeal, D.R., 2005. Calving of large tabular icebergs from ice shelf rift systems. Geophysical Research Letters, 32, L02501. doi:10.1029/2004GL020978.

Massom, R. A., Recent iceberg calving events in the Ninnis Glacier region, East Antarctica, Antarctic Science, 15 (2), 303313, 2003.

Massom, R.A. and 7 others. 2010. Examining the interaction between multi-year land fast sea ice and the Mertz Glacier Tongue, East Antarctica: another factor in ice sheet stability? $J$. Geophys. Res., 115(C12), C12027. (10.1029/2009JC006083.)
Nick, F.M., Oerlemans, J., 2006. Dynamics of tidewater glaciers: comparison of three models. Journal of Glaciology, 52, 183-190.

National Remote Sensing Centre, Indian Space Research Organisation. www.nrsc.gov.in

National Snow and Ice Data Center, State of the cryosphere: Ice shelves. http://nsidc.org/cryosphere/sotc/iceshelves.html.

[Online]

Rignot, E. Jacobs, S.S. Mouginot, J. Scheuchl, B., 2013. Iceshelf melting around Antarctica. Science, 341, 266-270.

Stevens, C. L., Sirguey P., Leonard G. H., Haskell T. G., 2013. “The 2013 Erebus Glacier Tongue calving event”, The Cryosphere, 7, 1333-1337, doi:10.5194/tc-7-1333-2013.

Warren, C.R., 1992. Iceberg calving and the glacioclimatic record. Progress in Physical Geography, 16, 253-282.

Willis, C. J., Macklin, J. T, Partington, K. C., Teleki, K. A, Rees, W.G, Williams, R. G,1996. Iceberg detection using ERS1 Synthetic Aperture Radar. Int. J. Remote Sens., 17,1777-1795.

Zhou Chunxia, Zhou Yu, E Dongchen, Wang Zemin, Sun Jiabing, 2012. "Estimation of ice flow velocity of calving glaciers using sar interferometry and feature tracking". Proc. 'Fringe 2011 Workshop', Frascati, Italy, 19-23 September 2011 (ESA SP-697, January 2012).

Zwally, H.J., Abdalati, W., Herring, T., Larson, K., Saba, J., Steffen, K., 2002. Surface melt-induced acceleration of Greenland Icesheet flow. Science, 297, 218-222. 